\title{
Pengaruh Variabel Makroekonomi Terhadap Index Harga Saham Syariah
}

\author{
Annisa Masruri Zaimsyah', Alvira 'Aina Ayun², Khofidlotur Rofi'ah', \\ Sri Herianingrum ${ }^{4}$ \\ Faculty of Economics and Business, Universitas Airlangga Surabaya ${ }^{1,2,3}$ \\ Departement Syariah Economy, Universitas Airlanggga Surabaya ${ }^{4}$ \\ Email: alvira.aina.ayun-2018@pasca.unair.ac.id
}

\begin{abstract}
The purpose of this paper to investigate macroeconomic indicators affects sharia stock prices in Asia Muslim majority countries. This research used inflation, interest rates and exchange rate in Indonesia, Malaysia, Saudi Arabia and Bangladesh. This research use data panels and multiple linear regression analyses using Ordinary Least Square (OLS) method as parameter. The results shows inflation and exchange rates have no effect in sharia stock prices, while interest rates have negative effect. Implications for investors who want to invest in stocks to attention macroeconomic variables that affect movement of stock price, information that related macroeconomic conditions, information that predict fluctuation stock price. This study has limitations only focus in four countries in Asia and only use three most dominant macro variables. Future research can improved other macroeconomic variables such world oil prices and gross domestic income. Novelty of this research examines the Sharia stock market in Muslim majority countries in Asia.
\end{abstract}

Keywords: Sharia stock price, inflation, interest rates, exchange rate.

\begin{abstract}
Abstrak: Tujuan makalah ini adalah untuk menyelidiki indikator ekonomi makro yang mempengaruhi harga saham syariah di negara-negara mayoritas Muslim Asia. Penelitian ini menggunakan inflasi, suku bunga dan nilai tukar di Indonesia, Malaysia, Arab Saudi dan Bangladesh. Penelitian ini menggunakan data panel dan analisis regresi linier berganda menggunakan metode Ordinary Least Square (OLS) sebagai parameter. Hasilnya menunjukkan inflasi dan nilai tukar tidak berpengaruh pada harga saham syariah, sedangkan tingkat bunga memiliki efek negatif. Implikasi bagi investor yang ingin berinvestasi dalam saham memperhatikan variabel ekonomi makro yang mempengaruhi pergerakan harga saham, informasi yang terkait dengan kondisi ekonomi makro, informasi yang memprediksi fluktuasi harga saham. Studi ini memiliki keterbatasan hanya fokus di empat negara di Asia dan hanya menggunakan tiga variabel makro yang paling dominan. Penelitian di masa depan dapat ditingkatkan dengan variabel ekonomi makro lainnya seperti harga minyak dunia dan pendapatan domestik bruto. Kebaruan dari penelitian ini meneliti pasar saham Syariah di negara-negara mayoritas Muslim di Asia.
\end{abstract}

Kata Kunci: Harga saham Syariah, Inflasi, Suku Bunga, Nilai Tukar. 


\section{PENDAHULUAN}

Globalisasi dan pertumbuhan yang lebih luas pada perdagangan investasi terintegrasi dengan pasar keuangan internasional dan partisipasi dari investor luar negeri memiliki keterkaitan dengan pasar saham global dan pasar nilai tukar luar negeri serta hubungan antara nilai tukar dan fluktuasi pasar saham (Megaravalli dan Sampagnaro, 2018). Krisis global pada tahun 2008 merupakan krisis yang menyebabkan banyak sistem keuangan runtuh, hal ini menyebabkan banyak peneliti mencari cara untuk bangkit dan mulai meneliti mengenai alasan keruntuhan dari sektor keuangan yang nantinya akan dijadikan landasan dalam pengambilan keputusan dan pembatas dalam pengambilan keputusan. Beberapa tahun terakhir, penelitian mengenai variabel ekonomi terutama ekonomi makro serta pengembangan pasar saham sebagai alternatif pendanaan di berbagai Negara mengalami peningkatan. Faktor ekonomi makro memiliki pengaruh yang signifikan dan berdampak terhadap pasar saham (Sukruoglu dan Temel, 2014). Hal ini disebabkan ekonomi makro membahas mengenai nilai tukar, inflasi, pengangguran, pertumbuhan ekonomi, ekspor import. Krisis global menyebabkan perubahan adanya perubahan variabel makroekonomi pada harga saham (Chang dan Rajput, 2018).

(Peiró, 2016) menambahkan bahwa perspektif masa depan suatu negara memiliki kontribusi terhadap pasar saham. Studi ini menunjukkan bahwa produksi industri dan tingkat bunga memiliki dampak signifikan pada harga saham di negara-negara Eropa. (Phan et al., 2015) menyatakan bahwa pertumbuhan ekonomi dan kinerja pasar saham cenderung bergerak ke arah yang sama. Akhirnya, keputusan investasi oleh manajer investasi dan investor menyesuaikan dengan kinerja pasar saham. Ketika kondisi pasar saham memburuk, investor cenderung bereaksi negatif, yaitu menjual saham, yang dapat memicu penurunan harga saham. Sebaliknya, peningkatan kinerja di pasar saham menyebabkan investor bereaksi positif dan hal inilah yang menyebabkan peningkatan harga saham.

Makro ekonomi merupakan salah satu faktor eksternal perusahaan yang memiliki pengaruh terhadap kinerja perusahaan baik secara langsung maupun tidak langsung. Menurut (Khan, 2012) variabel makro ekonomi mempengaruhi harga saham. Dimana variabel digunakan investor untuk mempertimbangkan variabel ekonomi makro ketika menilai saham pada suatu negara. Suku bunga, nilai tukar dan inflasi sangat penting di antara variabel-variabel makro ekonomi yang mempengaruhi harga saham.

Menurut data global religious futures project populasi muslim seluruh dunia mencapai 23,2\% pada 2019 dan akan meningkat hingga 30\% (PRC, 2015). Banyaknya muslim di dunia menjadi salah satu dasar dalam pengembangan produk ekonomi yang sesuai dengan kaidah Islam, salah satunya produk mengenai saham. Perkembangan Saham saat ini tidak berkutat hanya pada saham konvensional akan tetapi saham syariah mulai berkembang baik pada negara-negara Muslim maupun Negara mayoritas Muslim. Salah satunya di negara Indonesia sendiri di tahun 2000 meluncurkan saham syariah yaitu Jakarta Islamic Index (JII) kemudian disusul pada tahun 2011 Indeks Saham Syariah Indonesia (ISSI) kembali diluncurkan.

ISSI adalah indikator dari kinerja pasar saham syariah Indonesia dimana elemen ISSI adalah semua saham syariah yang termuat di Bursa Efek Indonesia dan termasuk di Daftar Efek Syariah (DES) yang dikeluarkan oleh OJK, sehingga BEI tidak menyeleksi 
atas saham syariah yang terdaftar ke dalam ISSI (www.idx.co.id) berikut merupakan data perkembangan harga saham syariah di negara muslim dan mayoritas muslim.

Gambar 1. Data Perkembangan Harga Saham Syariah di Negara Muslim dan Mayoritas Muslim

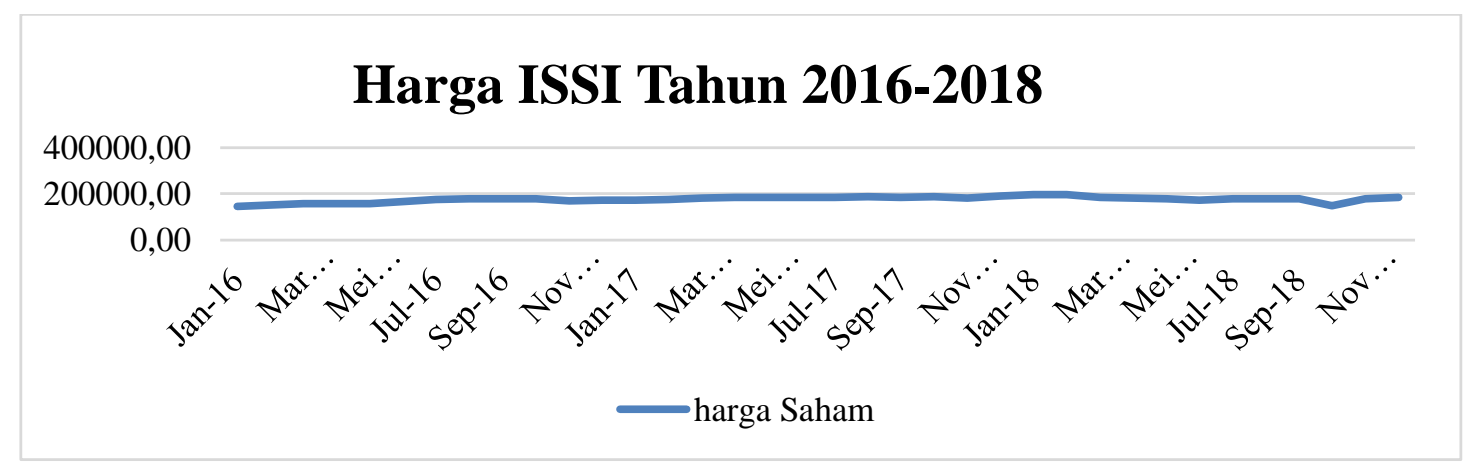

Sumber: www.idx.co.id

Dari gambar 1 terlihat harga saham ISSI menunjukkan pergerakan yang tidak terlalu signifikan baik naik ataupun turun, namun relatif terjadi kenaikan setiap bulannya. Menurut (Wahyudi dan Sani, 2014), volatilitas pasar saham Indonesia tidak hanya dipengaruhi oleh fenomena makroekonomi domestik, tetapi juga oleh perubahan kondisi ekonomi global. Ini sejalan dengan penelitian oleh (Hengchao dan Hamid, 2015) yang mengeksplorasi dampak krisis A.S. di pasar saham Asia-Pasifik, baik Islam dan konvensional. Sampel penelitian itu meliputi AS, Jepang, Cina, Malaysia, dan Indonesia. Studi ini mengungkapkan bahwa ada integrasi antara pasar saham di lima negara setelah krisis subprime A.S. Ini menunjukkan bahwa pasar saham ini rentan terhadap volatilitas keuangan dan makroekonomi eksternal.

Berikut merupakan FTSE Bursa Malaysia Emas Shariah (FTBMS) data pada tahun 2016-2019.

Gambar 2. Data Perkembangan Harga Saham Syariah di Negara Malaysia

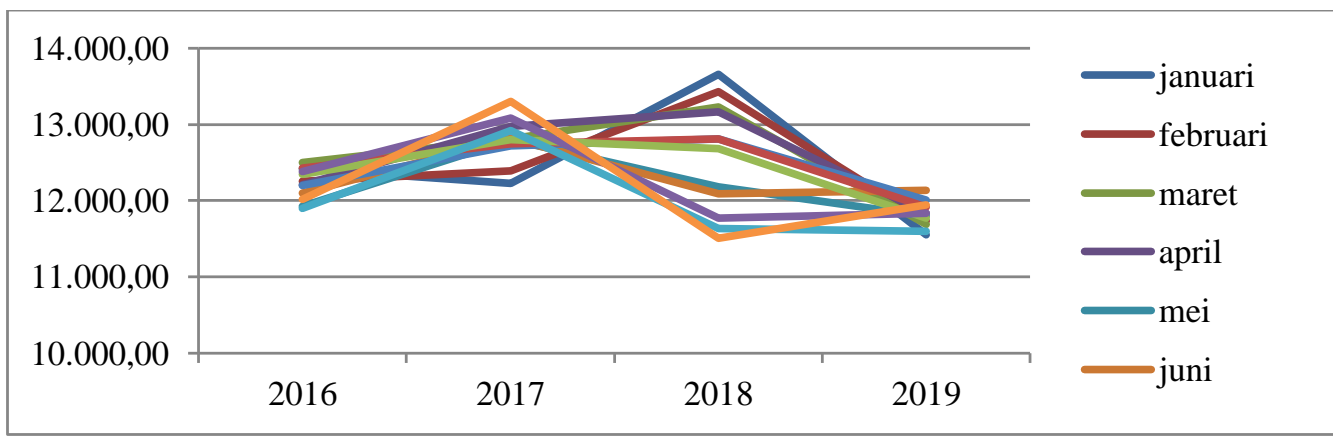

Sumber: www. Investing.com (Investing, 2020)

Pada gambar 2 menunjukkan adanya fluktuasi pada pasar saham di negara Malaysia. Pada tahun 2018 bulan januari menunjukkan kenaikan tertinggi diantara tahun 
sebelumnya. Selanjutnya merupakan data perkembangan harga saham syariah di negara Arab Saudi

Gambar 3. Data Perkembangan Harga Saham Syariah di Negara Arab Saudi

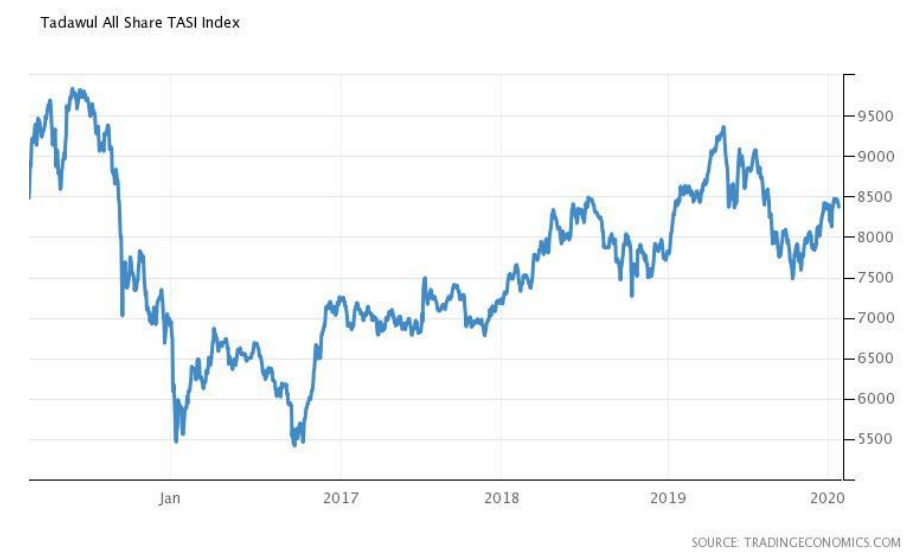

Sumber: tradingeconomics (Economic, 2020)

Terlihat dalam gambar 3 menunjukkan bahwa terjadinya fluktuasi dalam selama 4 tahun dimana pada tahun 2017 mengalami penurunan drastis dan mengalami kenaikan tertinggi pada akhir 2019 pada Saudi Arabia Stock Market. Selanjutnya merupakan data perkembangan harga saham syariah di negara Bangladesh.

Gambar 4. Data Perkembangan Harga Saham Syariah di Negara Bangladesh

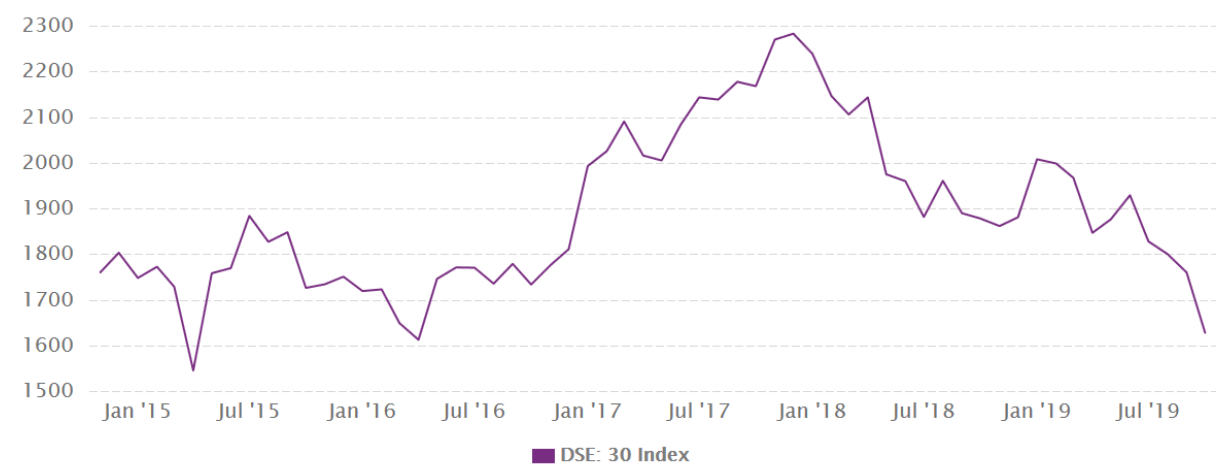

Sumber: CEIC data (CEIC, 2019)

Pada gambar 4 merupakan data perkembangan harga saham syariah di Bangladesh yaitu pasar saham syariah Dhaka Stock Exchange dimana nilai tertinggi bulan januari 2018 dan mengalami nilai terendah pada tahun 2015.

Banyak penelitian yang berkaitan dengan variabel makro ekonomi yang terait dengan harga saham. Penelitian yang dilakukan penulis merupakan pengembangan dari penelitian yang dilakukan oleh (Rjoub et al., 2009) mengenai efek makroekonomi pada tingkat pengembalian saham pada pasar saham Istanbul. Maka dari itu penelitian ini fokus 
untuk membahas terkait harga saham syariah di Negara-negara muslim maupun Negara dengan mayoritas muslim, sehingga penelitian ini meneliti saham syariah yang terdapat di Negara Muslim dan Negara Mayoritas Muslim di Asia. Negara-negara tersebut meliputi: Indonesia, Malaysia, Arab Saudi dan Bangladesh. Pemilihan keempat Negara ini dikarenakan adanya kelengkapan data mengenai Makro ekonomi dan harga saham syariah. Dari latar belakang yang telah dipaparkan oleh penulis maka dapat disimpulkan hipotesis dalam penelitian ini yaitu:

H1: Terdapat Pengaruh Inflasi terhadap Harga Saham Syariah di Negara Muslim dan Mayoritas Muslim di Asia

H2: Terdapat Pengaruh Suku Bunga terhadap Harga Saham Syariah di Negara Muslim dan Mayoritas Muslim di Asia

H3: Terdapat Pengaruh Nilai Tukar mata uang terhadap Harga Saham Syariah di Negara Muslim dan Mayoritas Muslim di Asia.

Paper ini akan disusun sebagai berikut: di bagian 2 disajikan tinjauan literature secara singkat dan jelas. Di bagian 3, menjelaskan terkait metode penelitian dan variabel, pada bagian 4 membahas hasil empiris dan temuan utama studi ini. Bagian kelima merangkum temuan studi dan memberikan kontribusi dan rekomendasi kebijakan bagi para pembuat kebijakan dan investor untuk mengambil keputusan dalam melakukan investasi saham syariah.

\section{KAJIAN TEORI}

Penelitian yang dilaksanakan Oleh (Omotor, 2010) yang berjudul Hubungan Inflasi Terhadap Pasar Saham di Nigeria. Dimana dalam penelitian ini menggunakan harga saham sebagai variabel dependen dan inflasi di Nigeria. Data yang digunakan adalah data bulanan mulai tahun 1989 hingga 2008. Penelitian ini mengemukakan hasil yaitu pengembangan pasar saham berdampak pada adanya hubungan yang efektif terhadap inflasi di Nigeria. Selanjutnya penelitian yang dilakukan oleh (Charles et al., 2012) mengenai hubungan antara saham dan nilai tukar di tujuh Negara Afrika. Salah satu Negara yang digunakan adalah Tunisia. Variabel yang digunakan dianalisa menggunakan kointegrasi model faktor kesalahan koreksi (VECM) dan analisis respon impuls untuk menentukan hubungan jangka panjang dan jangka pendek antara harga saham dan nilai tukar terhadap mata uang. Analisis kointegrasi menunjukkan terdapat hubungan jangka panjang antar harga saham dan nilai tukar di Tunisia, dimana depresiasi nilai tukar mendorong turunnya harga saham. Model koreksi kesalahan jangka pendek juga menunjukkan hasil yang sama (Charles et al., 2012)

Menurut (Tripathi dan Kumar, 2015) dalam penelitian terkait hubungan jangka panjang antara inflasi dan pasar saham BRICS menggunakan data panel untuk periode Maret 2000 hingga September 2013. Hasil korelasi menunjukkan hubungan negatif inflasi yang signifikan antara indeks harga saham dan tingkat inflasi di Rusia dan hubungan yang positif signifikan di India dan Cina (Tripathi dan Kumar, 2015). Sedangkan menurut (Khan, 2012) yang meneliti mengenai bagaimana dampak tingkat suku bunga, nilai tukar dan inflasi terhadap indeks harga saham Karachi Pakistan dengan menggunakan regresi berganda OLS dan teknik ANOVA. Penelitian yang dilakukan Khan menggunakan data 
bulanan saham dengan jangka waktu sepuluh tahun yang mencangkup periode 31 Juli 2001 hingga 30 Juni 2010. Hasil menunjukkan pasar saham memiliki hubungan positif dengan inflasi tetapi berhubungan negatiff dengan suku bunga dan nilai tukar. Selanjutnya menurut penelitian yang dilakukan oleh (Chang dan Rajput, 2018) mengenai hubungan variabel makroekonomi dan harga saham. Dimana pada jangka pendek menunjukkan bahwa nilai tukar memiliki efek asimetris pada harga saham sebelum dan sesudah masa krisis, IPI hanya berpengaruh pada sebelum krisis. Pada jangka panjang, hasil menunjukkan IPI dan nilai tukar memiliki efek asimetris pada harga saham selama sebelum krisis, CPI memiliki asimetris efek pada periode sebelum krisis dan nilai tukar mempengaruhi pada sesudah krisis terhadap harga saham.

Menurut (Mawardi et al., 2019) pada penelitian mengenai dampak makroekonomi terhadap harga saham syariah di Indonesia mempengaruhi secara signifikan pada variabel inflasi, indeks produksi industri dan suku bunga sehingga dapat menstimulasi adanya pasar modal Islam di Indonesia. Perbedaan penelitian ini dengan penelitian-penelitian terdahulu, penelitian ini meneliti terkait makro ekonomi terhadap harga saham syariah, dimana kebanyakan penelitian terdahulu hanya membahas saham konvensional dan juga penelitian ini meneliti Negara-negara yang Mayoritas Muslim dan Negara Muslim di Asia.

Pembahasan mengenai pasar saham dilakukan oleh (Rjoub et al., 2009) mengenai performa dari teori harga arbitrase atau APT pada pasar saham Istanbul menurut data bulanan dari januari 2001 hinga september 2005. Penelitian menggunakan 6 variabel makroekonomi yaitu struktur pembentukan suku bunga, inflasi yang tidak diantisipasi, risiko premium, nilai tukar, penawaran uang serta tingkat pengangguran. Variabel tersebut diuji menggunakan teknik OLS atau ordinary least square, hasil menunjukkan adanya perbedaan besar diantara pasar portofolio terhadap variabel makroekonomi. Dalam penelitian ini tidak ada nya obligasi di pasar Turki.

Pada pasar saham afrika selatan, penelitian yang dilakukan oleh (Gupta dan Modise, 2013) mengenai prediksi tingkat pengembalian saham menggunakan variabel makroekonomi dimana mengambil sampel pada taun 1990:01 hingga 1996:12 untuk insample dan tahun 1997:01 hingga 2010:06 untuk out-sample. Hasil menunjukkan pada insample variabel suku bunga, pertumbuhan produksi minyak dunia, pasokan uang memiliki pengaruh dalam memprediksi pada jangka pendek atas pengembalian pasar saham di afrika. Pada prediksi yang digunakan oleh out-sample variabel yang berpengaruh adalah suku bunga dan uang beredar pada jangka pendek. Laju inflasi menunjukkan prediksi untuk 6 bulan ke depan. Model yang digunakan dalam penelitian menunjukkan pentingnya suku bunga dalam menjelaskan perilaku pengembalian saham.

Berbeda dengan penelitian sebelumnya yang menitik beratkan pada faktor makroekonomi, penelitian yang dilakukan oleh (Jaballah et al., 2018) mengenai dampak kepatuhan syariah terhadap valuasi saham. Dimana dalam penelitian melihat bagaimana efek hara terhadap adanya penambahan dan penghapusan dari Dow Jones Islamic Market Index (DJMI). Penelitian ini menggunakan perusahaan dari negara muslim dan AS pada periode 2000-2017. Hasil penelitian yang dilakukan adalah penambahan indeks islam mengarah pada reaksi positif pasar saham di negara muslim tetapi berdampak negatif pada pasar saham Amerika Serikat. Begitu pula sebaiknya adanya penghapusan indeks Islam menyebabkan adanya reaksi negatif pada pasar saham negara muslim namun berdampak positif pada Amerika Serikat. Hal ini disebabkan karena pada negara muslim investor memiliki kecenderungan atas kepatuhan syariah karena adanya keyakinan yang dianut 
sementara Amerika bereaksi negatif karena adanya persepsi negatif terhadap islam dan adanya batasan mengenai kepatuhan syariah.

Inflasi. Inflasi diukur menggunakan indeks harga konsumen dimana mencerminkan adanya persentase perubahan tahunan dalam biaya rata-rata konsumen dalam memperoleh barang dan jasa yang dapat diperbaiki atau diubah pada interval yang ditentukan setiap tahunnya (Datacatalog.worldbank.org, 2018). Inflasi akan mempengaruhi pasar saham secara negatif. Pertumbuhan inflasi dianggap sebagai keadaan buruk bagi pasar saham karena menggambarkan ekonomi yang buruk suatu Negara sehingga investor merasa tidak nyaman apabila menginvestasikan uangnya di pasar saham (Khan, 2012).

Suku Bunga. Tingkat suku bunga ditentukan oleh permintaan dan pasokan dana pinjaman. Teori bunga klasik dianggap hanya sebagai arus pendapatan dari tabungan sementara ekonom non-klasik menganggap bunga tidak hanya pendapatan dari tabungan akan tetapi juga dari kredit bank dan investasi (Pal, 2018). Tingkat suku bunga dan nilai tukar berbanding terbalik dengan harga saham. Kenaikan suku bunga menyebabkan penurunan harga saham karena diperlukan tingkat pengembalian saham yang menyebabkan penurunan harga saham (Khan, 2012).

Nilai Tukar. Nilai Tukar merupakan harga mata uang di suatu negara dengan mata uang di negara lain. Nilai Tukar dinyatakan dalam mata uang negara lain. Nilai Tukar dapat dikatakan sebagai perbandingan nilai. Hal ini berarti, ketika terjadi tukar menukar antara dua mata uang yang berbeda, hal ini menimbulkan adanya perbandingan nilai atau harga dari kedua mata uang tersebut. Hal ini mengakibatkan, terdapat lebih banyak ketidakpastian dalam hubungan antara pasar valuta asing dan pasar saham internasional. (Mechri et al., 2019). Nilai tukar memiliki hubungan terhadap harga saham. Investor asing dapat terpengaruh ketika mata uang local dapat menguat dan menjadi lemah. Nilai tukar memiliki hubungan yang negative terhadap harga saham. harga saham berkurang ketika nilai tukar yang tinggi (Khan, 2012).

\section{METODOLOGI}

Penelitian ini menggunakan data-data yang didapatkan melalui kepustakaan dan internet (data sekunder). Ruang lingkup penelitian ini adalah Harga saham Syariah di Negara Muslim dan Mayoritas Muslim yaitu menggunakan variabel Makro ekonomi dan variabel Harga Saham Syariah di Indonesia, Malaysia, Arab Saudi dan Bangladesh.

Tabel 1. Daftar Index Saham Syariah yang diteliti

\begin{tabular}{lll}
\hline \multicolumn{1}{c}{ Negara } & \multicolumn{1}{c}{ Index Saham Syariah } & \\
\hline Indonesia & Index Saham Syariah Indonesia & ISSI \\
\hline Malaysia & FTSE Bursa Malaysia Emas Index & FBMS \\
\hline Arab Saudi & Tadawul Stock Exchange Index & \\
\hline Bangladesh & Dhaka Stock Exchange & DSE \\
\hline
\end{tabular}


Penelitian ini merupakan penelitian kuantitatif menggunakan data sekunder yang berupa data panel. Adapun yang menjadi variabel dependent dari penelitian ini yaitu Harga saham syariah dan variabel independen nya adalah Inflasi, Suku Bunga dan Nilai Tukar. Ketiga variabel makro tersebut, dijadikan variabel independent dikarenakan hal ini mudah dimengerti dan variabel tersebut banyak digunakan pada penelitian sebelumnya dan sebagai dasar dalam melakukan investasi termasuk berinvestasi di Pasar saham.

Penelitian ini dilakukan dengan melihat data harga saham dari berbagai Negara yang dipublikasi oleh CEIC data dari Negara Malaysia, Bangladesh. Sedangkan data dari Indonesia diambil dari Akun resmi Bursa Efek Indonesia dan Bank Indonesia.

Tabel 2. Sumber Variabel Penelitian

\begin{tabular}{ll}
\hline Variabel & Sumber \\
\hline Harga Saham ISSI & www.idx.co.id \\
\hline Inflsi Indonesia & www.bi.go.id \\
\hline Suku Bunga Indonesia & $\underline{\text { www.bi.go.id }}$ \\
\hline Nilai Tukar Indonesia & $\underline{\text { www.bi.go.id }}$ \\
\hline Harga Saham Malaysia & ceic.data.com \\
\hline Inflasi Malaysia & ceic.data.com \\
\hline Suku Bunga Malaysia & ceic.data.com \\
\hline Nilai Tukar Malaysia & ceic.data.com \\
\hline Harga Saham Arab Saudi & ceic.data.com \\
\hline Inflasi Arab Saudi & ceic.data.com \\
\hline Suku Bunga Arab Saudi & ceic.data.com \\
\hline Nilai Tukar Arab Saudi & ceic.data.com \\
\hline Harga Saham Bangladesh & ceic.data.com \\
\hline Inflasi Bangladesh & ceic.data.com \\
\hline Suku Bunga Bangladesh & ceic.data.com \\
\hline Nilai Tukar Bangladesh & ceic.data.com \\
\hline
\end{tabular}

Objek penelitian ini adalah Pasar Saham Syariah di 4 Negara yaitu Indonesia, Malaysia, Arab Saudi dan Bangladesh. Metode analisis regresi linier berganda menggunakan metode Ordinary Least Square (OLS) untuk mengukur parameter. Keuntungan menggunakan OLS ini adalah metode yang cocok digunakan untuk data panel. Variabel independen yang digunakan dalam penelitian adalah: (1) Inflasi. Tingkat inflasi mencerminkan rata-rata biaya keseluruhan barang dan jasa yang dibeli oleh konsumen. Banyak peneliti mengeksploitasi inflasi dalam penelitian mereka mengenai pentingnya inflasi sebagai penentu dinamika pasar saham (Hatemi. J and Irandoust 2012), (Bahamani, 2016) (MECHRI et al., 2019). (2) Suku Bunga. Suku bunga pada penelitian ini merupakan suku bunga acuan dari Negara-negara yang menjadi sampel pada penelitian. (3) Nilai Tukar. Nilai tukar dalam penelitian ini merupakan nilai tukar dari mata uang Negara yang menjadi sampel penelitian ini terhadap dollar amerika serikat.

Dengan variabel tersebut maka model pengembangan hipotesis sebagai berikut: 
Gambar 5. Model Penelitian

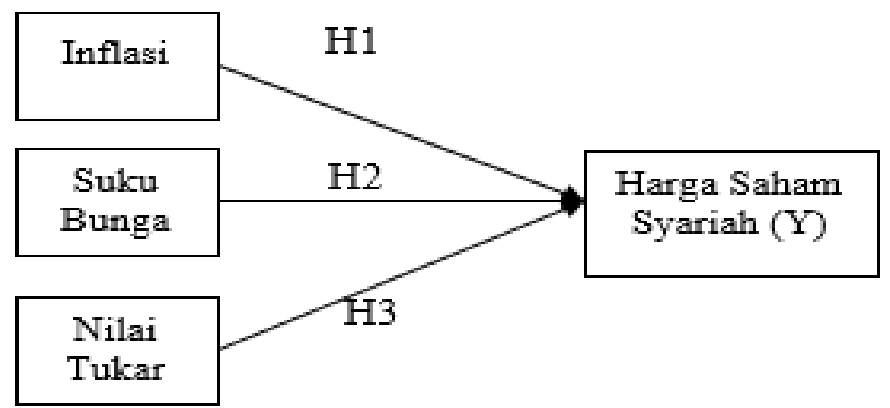

Sumber: (Data Olahan, 2019)

Untuk menentukan model mana yang akan digunakan dalam pengolahan regresi data panel pada penelitian ini, maka perlu dilakukan pengujian dengan menggunakan Hausman test serta chow test. Test ini bertujuan untuk mengetahui model mana yang cocok antara Common Effect Models (CEM), Fixed Effect Models (FEM) ataupun Random Effect Models (REM). Chow test dilakukan untuk memilih antara model Common Effect Models dan Fixed Effect Models. Hausman test dilakukan untuk menentukan apakah menggunakan Fixed Effect Models atau Random Effect Models.

Model regresi data panel pada penelitian ini yakni:

$$
\begin{aligned}
& Y_{\mathrm{i}, \mathrm{t}-1}=\alpha+\beta_{1} \mathrm{X}_{1 \mathrm{i}, \mathrm{t}-1}+\beta_{2} \mathrm{X}_{2 \mathrm{i}, \mathrm{t}-1}+\beta_{3} \mathrm{X}_{3 \mathrm{i}, \mathrm{t}-1}+\varepsilon_{\mathrm{i}, \mathrm{t}-1} \ldots . \\
& \text { Keterangan: } \\
& \mathrm{Y}: \text { Indeks Harga Saham Syariah } \\
& \alpha \quad: \text { Konstanta } \\
& \beta \quad: \text { Koefisien regresi } \\
& \mathrm{X}_{1}: \text { Inflasi } \\
& \mathrm{X}_{2}: \text { Suku Bunga } \\
& \mathrm{X}_{3}: \text { Nilai Tukar }
\end{aligned}
$$

\section{HASIL DAN PEMBAHASAN}

Pada bagian ini membahas mengenai hasil uji serta analisa tiap variabel. Pada tabel 3 menunjukkan rata-rata standar deviasi masing-masing variabel yang diteliti.

Tabel 3. Statistik Deskriptif Variabel

\begin{tabular}{llllll}
\hline Variabel & N & Mean & Maximum & Minimum & St. Deviasi \\
\hline Harga Saham & 144 & 505156.15 & 197464 & 4119 & 73045.33 \\
\hline Inflasi & 144 & 3.322 & 6.12 & -0.7 & 1.819 \\
\hline Suku Bunga & 144 & 4.423 & 7.53 & 1.64 & 1.859 \\
\hline Nilai Tukar & 144 & 25355 & 83970 & 3192 & 31970.73 \\
\hline
\end{tabular}

Sumber: (Data Diolah, 2019) 
Setelah melakukan uji statistik deskriptif, pengujian statistik deskriptif ini dimaksudkan untuk mengetahui nilai minimum dan maksimum per variabel yang digunakan dalam penelitian. Uji selanjutnya yaitu dengan uji Chow dan uji Haussman. Dalam OLS, Uji Chow dan Haussman berfungsi untuk memilih model mana yang lebih tepat dan terbaik diantara Common Effect Models (CEM), Fixed Effect Model (FEM) dan Random Effect Model (REM).

Uji chow berfungsi dalam memilih antara model Ordinary Last Square (OLS). Uji chow dilakukan antara Fixed Effect Model (FEM) dan Common Effect Models (CEM). Apabila hasil uji menunjukkan nilai signifikansi dibawah angka probabilitas alpha 0.05 dari hasil uji chow dapat ditarik kesimpulan model regresi menggunakan data panel dengan fixed effect model lebih baik. Hasil regresi uji chow terhadap variabel dalam penelitian ini ditunjukkan dalam Tabel 4

Tabel 4. Hasil Uji Chow

Redundant Fixed Effects Tests

\begin{tabular}{lrrr}
\hline \hline \multicolumn{1}{c}{ Effects Test } & Statistic & d.f. & Prob. \\
\hline \hline Cross-section F & 5394.811284 & $(3,136)$ & 0.0000 \\
Cross-section Chi-square & 684.615121 & 3 & 0.0000 \\
\hline \hline
\end{tabular}

\begin{tabular}{lcccc}
\hline \multicolumn{1}{c}{ Variable } & Coefficient & Std. Error & t-Statistic & Prob. \\
\hline \hline C & -93347.59 & 15885.65 & -5.876222 & 0.0000 \\
X1 & 4846.474 & 4045.236 & 1.198069 & 0.2329 \\
X2 & 44265.94 & 4726.159 & 9.366156 & 0.0000 \\
X3 & -2.794279 & 0.265655 & -10.51845 & 0.0000 \\
\hline \hline R-squared & 0.472335 & Mean dependent var & 50414.37 \\
Adjusted R-squared & 0.460947 & S.D. dependent var & 73236.09 \\
S.E. of regression & 53770.12 & Akaike info criterion & 24.65040 \\
Sum squared resid & $4.02 \mathrm{E}+11$ & Schwarz criterion & 24.73327 \\
Log likelihood & -1758.503 & Hannan-Quinn criter. & 24.68407 \\
F-statistic & 41.47492 & Durbin-Watson stat & 0.084385 \\
Prob(F-statistic) & 0.000000 & & \\
\hline \hline
\end{tabular}

Sumber: (Data diolah, Data Sekunder, 2019)

Tabel 4 menampilkan hasil uji yang disajikan dalam bentuk test cross section fixed effect dengan nilai probabilitas yang digunakan lebih dari 0.05 hal ini berarti model regresi data panel dengan menggunakan fixed effect model tepat diterapkan untuk memprediksikan variabel dependen. 
Uji Haussman digunakan untuk memilih model yang tepat antara Fixed Effect Model (FEM) atau Random Effect Model (REM). Apabila hasil uji Haussman menunjukkan angka signifikan kurang dari nilai profitabilitas alpha 0.05 maka penelitian yang dilakukan menggunakan model regresi data panel dengan fixed effect model. Hasil uji Haussman terhadap variabel yang digunakan dalam penelitian dipaparkan pada tabel 5

Tabel 5. Hasil Uji Haussman

\begin{tabular}{lccc}
\hline \hline \multicolumn{1}{c}{ Test Summary } & Chi-Sq. Statistic & Chi-Sq. d.f. & Prob. \\
\hline \hline Cross-section random & 16184.433841 & 3 & 0.0000 \\
\hline \hline
\end{tabular}

Cross-section random effects test comparisons:

\begin{tabular}{crrrr} 
Variable & \multicolumn{1}{c}{ Fixed } & \multicolumn{1}{c}{ Random } & \multicolumn{1}{c}{ Var(Diff.) } & \multicolumn{1}{c}{ Prob. } \\
\hline \hline X1 & 133.293291 & 4846.473716 & 2327.484340 & 0.0000 \\
X2 & -8562.545313 & 44265.939426 & 628613.820756 & 0.0000 \\
X3 & 0.088450 & -2.794279 & 0.019765 & 0.0000 \\
\hline \hline
\end{tabular}

Cross-section random effects test equation:

Dependent Variable: Y

Method: Panel Least Squares

Periods included: 36

Cross-sections included: 4

Total panel (unbalanced) observations: 143

\begin{tabular}{|c|c|c|c|c|}
\hline Variable & Coefficient & Std. Error & t-Statistic & Prob. \\
\hline $\mathrm{C}$ & 85723.29 & 5254.894 & 16.31304 & 0.0000 \\
\hline $\mathrm{X} 1$ & 133.2933 & 376.4279 & 0.354100 & 0.7238 \\
\hline $\mathrm{X} 2$ & -8562.545 & 904.9049 & -9.462370 & 0.0000 \\
\hline $\mathrm{X} 3$ & 0.088450 & 0.142711 & 0.619786 & 0.5364 \\
\hline \multicolumn{5}{|c|}{ Effects Specification } \\
\hline \multicolumn{5}{|c|}{ Cross-section fixed (dummy variables) } \\
\hline R-squared & 0.995603 & Mean dependent var & & 50414.37 \\
\hline Adjusted R-squared & 0.995409 & S.D. dependent var & & 73236.09 \\
\hline S.E. of regression & 4962.295 & Akaike info criterion & & 19.90484 \\
\hline Sum squared resid & $3.35 \mathrm{E}+09$ & Schwarz criterion & & 20.04987 \\
\hline Log likelihood & -1416.196 & Hannan-Quinn criter. & & 19.96377 \\
\hline F-statistic & 5132.257 & Durbin-Watson stat & & 1.004522 \\
\hline Prob(F-statistic) & 0.000000 & & & \\
\hline
\end{tabular}

Sumber: (Data diolah, Data Sekunder, 2019) 
Hasil Uji Haussman yang disajikan menunjukkan probabilitas cross section random lebih kecil dari 0.05 maka dapat disimpulkan bahwa model yang tepat adalah Fixed Effect Model. Selanjutnya adalah melakukan Uji F dimana uji ini digunakan untuk mengetahui bagaimana pengaruh variabel independen terhadap variabel dependen apabila diuji secara bersamaan atau simultan. Hasil uji $\mathrm{F}$ pada data panel yang dilakukan dalam penelitian ini dapat dilihat pada tabel 6

Tabel 6. Hasil Uji F

\begin{tabular}{lll}
\hline Variabel Dependen & Prob & Kesimpulan \\
\hline Harga Saham Syariah & 0.0000 & Signifikan \\
\hline
\end{tabular}

Sumber: (Data diolah, Data Sekunder, 2019)

Berdasarkan hasil pengujian yang dipaparkan pada Tabel 6, nilai probabilitas yang dihasilkan adalah 0.0000 dimana nilai tersebut lebih kecil dari pada 0.05. Hasil uji $F$ tersebut memperlihatkan variabel independen berupa inflasi, suku bunga dan nilai tukar memiliki pengaruh yang signifikan atas variabel dependen yaitu harga saham syariah dan juga berpengaruh secara simultan.

Setelah didapatkan hasil uji $\mathrm{F}$ selanjutnya adalah Uji t, dimana uji ini digunakan untuk mengetahui pengaruh masing-masing variabel independen secara parsial. Hasil uji t dalam fixed effect model dijelaskan dalam pada Tabel 7 berikut:

Tabel 7. Hasil Uji t

\begin{tabular}{llllll}
\hline Variabel & koefisien & t-statistic & Prob & Kesimpulan & Hipotesis \\
\hline C & 85723.29 & 16.31304 & 0.0000 & & \\
\hline Inflasi (X1) & 133.2933 & 0.354100 & 0.7238 & Tidak Berpengaruh & H1 ditolak \\
\hline $\begin{array}{l}\text { Suku Bunga } \\
\text { (X2) }\end{array}$ & -8562.545 & 9.462370 & 0.0000 & Bepengaruh (-) & H2 diterima \\
\hline $\begin{array}{l}\text { Nilai Tukar } \\
\text { (X3) }\end{array}$ & 0.088450 & 0.619786 & 0.5364 & Tidak Berpengaruh & H3 ditolak \\
\hline
\end{tabular}

Sumber: (Data diolah, Data Sekunder, 2019)

Dari hasil uji yang telah dipaparkan maka persamaan regresi yang terbentuk berdasarkan hasil uji t pada tabel 6 untuk model regresi adalah sebagai berikut:

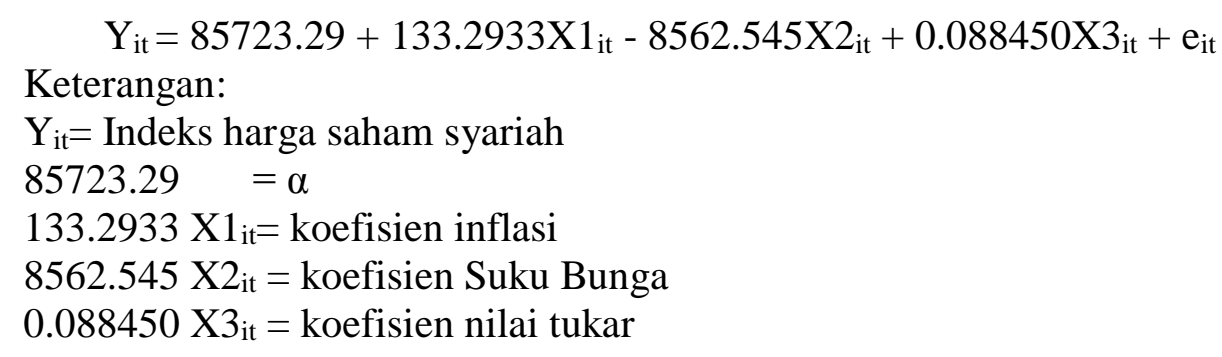


Hasil uji goodness of fit model bertujuan untuk mencari tahu seberapa besar pengaruh variabel-variabel independen dalam suatu penelitian terhadap variabel dependen. Hasil uji goodness of fit model dapat dilihat pada Tabel 8

Tabel 8. Hasil Uji Goodnes of Fit Model

\begin{tabular}{lll}
\hline Variabel Dependen & $\boldsymbol{R}$ Square & Adjusted $\boldsymbol{R}$ Square \\
\hline Harga Saham Syariah & 0.995603 & 0.995409 \\
\hline
\end{tabular}

Sumber: (Data diolah, Data Sekunder, 2019)

Hasil uji pada Tabel 8 menjelaskan adanya model yang sesuai yaitu antara pengaruh inflasi, suku bunga dan nilai tukar terhadap harga saham syariah. Hasil uji goodness of fit model pada tabel 8 menunjukkan bahwa adjusted $R$ square memiliki nilai yaitu sebesar 0.99529 atau $99.53 \%$ terhadap variabel dependen yang menandakan variabel yang digunakan dalam penelitian mewakili 99 persen terhadap variabel dependen dan $0.47 \%$ dipengaruhi oleh variabel lain yang tidak diteliti.

\section{DISKUSI}

Pengaruh Inflasi terhadap Harga Saham Syariah. Variabel inflasi memiliki koefisien regresi sebesar 133.2933 terhadap harga saham syariah dengan signifikansi value 0.7238 , nilai signifikansi lebih besar dari 0.05 menunjukkan bahwa inflasi tidak berpengaruh secara signifikan terhadap harga saham. Hasil yang didapatkan dalam penelitian ini sesuai dengan hasil penelitian yang dilakukan (Omotor, 2009) dan (Khan, 2012) dimana dalam penelitian yang dilakukan menghasilkan variabel inflasi tidak memiliki pengaruh terhadap saham.

Gambar 6. Pergerakan Inflasi

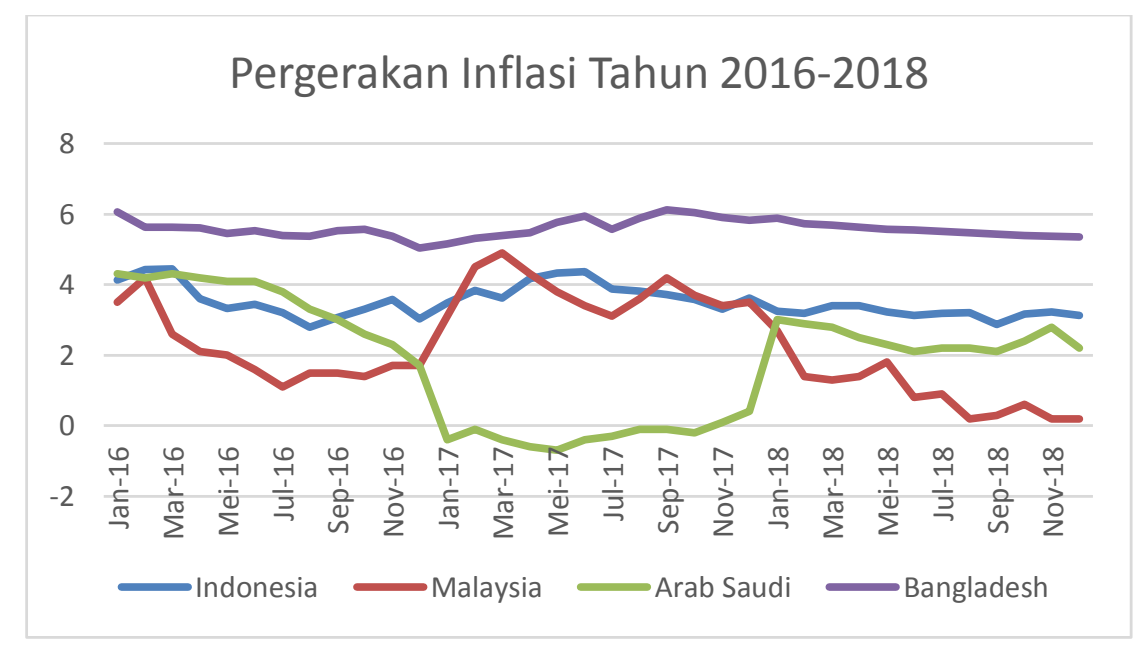

Dari Gambar 6 terlihat Inflasi di Indonesia berada pada 2 sampai 4 persen. Sedangkan Malaysia mengalami penurunan dan kenaikan inflasi dan pada Negara Arab Saudi sempat terjadi deflasi pada tahun 2017 akan tetapi mengalami inflasi pada tahun 2018 dan Bangladesh relative memiliki inflasi pada angka 6 persen. Dari gambar 3 ini 
inflasi tidak berpengaruh terhadap harga saham padahal ketika harga saham terus meningkat dan tingkat inflasi yang tinggi maka harga saham akan turun jauh drastis akibat dari inflasi yang tinggi. Tidak terpengaruh nya inflasi atas indeks harga saham syariah dikarenakan harga saham syariah karena pada saham syariah lebih saham bergerak pada sektor riil sehingga meski inflasi tidak mempengaruhi secara signifikan pada harga saham karena tingkat pengembalian akan selalu ada walau kecil.

Pengaruh Suku Bunga terhadap Harga Saham Syariah. Variabel suku bunga memiliki nilai koefisien sebesar -8562.545 dengan tingkat signifikan sebesar 0.000 dimana nilai dari variabel suku bunga lebih rendah dari 0.05 menunjukkan suku bunga berpengaruh negative pada variabel harga saham syariah. Hasil ini didukung penelitian (Muktadir, 2013) yang menemukan suku bunga memiliki pengaruh negative terhadap harga saham. Kenaikan suku bunga 1\% menyebabkan penurunan harga saham sebesar 8562.545 harga saham syariah di Negara Muslim dan mayoritas Muslim. Dan penelitian ini menolak penelitian (Balagobei, 2017) dan (Laichena dan Obwogi, 2015) yang mengatakan suku bunga memiliki pengaruh positif terhadap harga saham.

Gambar 7. Grafik Perkembangan Suku Bunga

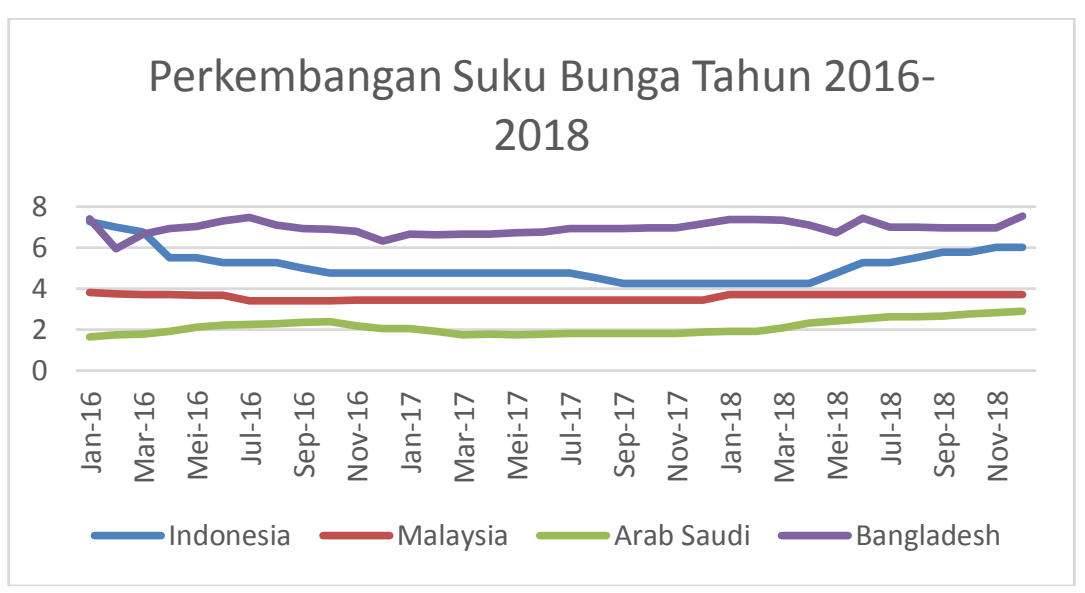

Pada Gambar 7 menggambarkan suku Bunga Bangladesh yang paling tinggi dibandingkan dengan Indonesia, Malaysia dan Arab Saudi. Pada penelitian ini didapatkan apabila suku bunga naik maka akan menurunkan harga saham syariah. Pada dasarnya saham dan suku bunga merupakan dua hal yang berlawanan. Dari segi perusahaan sendiri, suku bunga menjadi biaya modal, sedangkan dari pandangan investor suku bunga merupakan cost of opportunity atau kesempatan. Setiap kenaikan atau penurunan laba bersih perusahaan akibat biaya yang dikeluarkan maka akan menyebabkan penurunan harga saham. Naiknya tingkat suku bunga kredit memiliki kemungkinan akan menghambat kegiatan ekspansi perusahaan, karena perusahaan tidak memiliki modal yan cukup untuk ekspansi dan apabila meminjam di lembaga keuangan akan menerima suku bunga kredit yang kurang menguntungkan perusahaan. Akibatnya laba perusahaan menjadi turun dan akan berdampak terhadap harga saham yang juga menurun. 
Pengaruh Nilai Tukar terhadap Harga Saham Syariah. Variabel nilai tukar memiliki koefisien 0.088450 dengan nilai signifikan 0.5364 dimana nilai signifikansi memiliki nilai lebih besar dari 0.05 hal ini menunjukkan bahwa nilai tukar mata uang Negara yang diteliti tidak memiliki pengaruh negative maupun positif terhadap harga saham syariah di Negara tersebut.

Gambar 8. Perkembangan Nilai Tukar

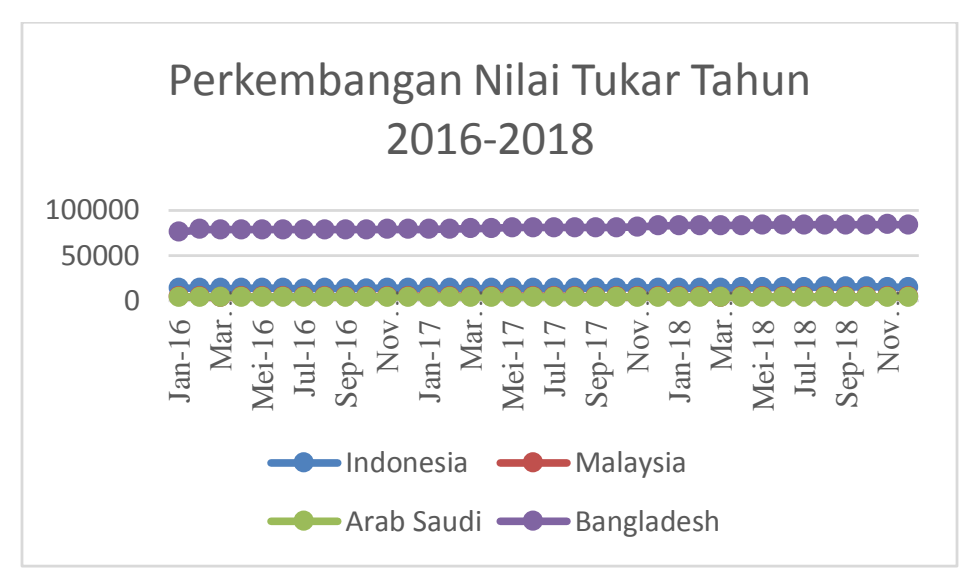

Pergerakan nilai tukar relative stabil. Tidak adanya pengaruh signifikan mengindikasikan bahwa kecilnya nilai tukar dan tidak berdampak besar pada naik turunnya harga saham. Sehingga secara praktis mengimplikasikan bahwa pemerintah harus mengambil langkah-langkah yang tepat untuk memperkuat tingkat nilai tukar dari mata uang Negara terhadap dollar Amerika Serikat.

\section{KESIMPULAN}

Tujuan dari penelitian ini adalah mencari faktor makroekonomi apa yang mempengaruhi harga saham pada negara muslim dan mayoritas muslim. Hasil yang didapatkan pada penelitian ini adalah penelitian ini menggunakan metode fixed effect model dimana variabel inflasi dan variabel nilai tukar tidak berpengaruh terhadap harga saham syariah, sedangkan variabel suku bunga memiliki pengaruh yang negative terhadap harga saham syariah. Pada uji F atau secara simultan variabel Inflasi, Suku Bunga dan Nilai tukar memiliki pengaruh yang bersamaan dengan Harga Saham Syariah.

Hasil penelitian ini memiliki implikasi yang diperuntukkan bagi para investor yang ingin melakukan investasi pada saham dianjurkan untuk memberikan perhatian atas informasi mengenai perubahan variabel makro ekonomi, karena dengan informasi tersebut dapat mengetahui pergerakan harga saham, baik informasi terkait keadaan ekonomi makro dalam negeri maupun luar negeri. Segala informasi yang memiliki kaitan dengan pergerakan harga saham harus diperhatikan. Informasi mengenai variabel makro tersebut diperlukan untuk memprediksi fluktuasi harga saham di Indonesia, Malaysia, Arab Saudi dan Bangladesh. Studi ini memiliki beberapa keterbatasan yaitu hanya berfokus pada empat Negara di Asia saja dan hanya 3 variabel makro yang paling dominan saja yang diteliti. Namun penelitian dapat lebih ditingkatkan dengan memasukkan variabel makro ekonomi yang lain seperti harga minyak dunia dan pendapatan domestic bruto. 


\section{DAFTAR PUSTAKA}

Balagobei, S. (2017). Macroeconomic Variables and Stock Market Returns in Sri Lanka. Asian Journal of Finance \& Accounting.

CEIC. (2019). Bangladesh Dhaka Stock Exchange. Retrieved January 23, 2020, from CEIC data website: https://www.ceicdata.com/en/bangladesh/dhaka-stock-exchangeindex

Chang, B. H., and Rajput, S. K. O. (2018). Do the Changes in Macroeconomic Variables Have a Symmetric or Asymmetric Effect on Stock Prices? Evidence from Pakistan. South Asian Journal of Business Studies, 7(3), 312-331. https://doi.org/10.1108/SAJBS-07-2018-0077.

Charles, B., A. N. O., and A., B. K. (2012). Article information: African Journal of Economic and Management Studies, 2(2), 143-164.

Datacatalog.worldbank.org. (2018). No Title.

Economic, T. (2020). Saudi Arabia Stock Index. Retrieved January 23, 2020, from tradingeconomic.com website: https://tradingeconomics.com/saudi-arabia/stockmarket.

Gupta, R., and Modise, M. P. (2013). Macroeconomic Variables and South African Stock Return Predictability. Economic Modelling, 30(1), 612-622. https://doi.org/10.1016/j.econmod.2012.10.015.

Hengchao, Z., and Hamid, Z. (2015). The Impact of Subprime Crisis on Asia-Pacific Islamic Stock Markets. Journal of Asia-Pacific Business, 16(2), 105-127. https://doi.org/10.1080/10599231.2015.1028304.

Investing. (2020). FTSE Bursa Malaysia Emas. Retrieved January 23, 2020, from investing.com website: https://www.investing.com/indices/ftse-malaysia-emas.

Jaballah, J., Peillex, J., and Weill, L. (2018). Is Being Sharia compliant worth it? Economic Modelling, 72(April 2017), 353-362. https://doi.org/10.1016/j.econmod.2018.02.011.

Khan, Z. (2012). Impact of Interest Rate, Exchange Rate and Inflation on Stock Returns of Kse 100 Index. International Journal of Economics and Research, 142-155.

Laichena, K. E., and Obwogi, T. N. (2015). Effects of Macroeconomic Variables on Stock Returns in The East African Community Stock Exchange Market. International Journal of Education and Research.

Mawardi, I., Widiastuti, T., and Sucia Sukmaningrum, P. (2019). The Impact of Macroeconomic on Islamic Stock Prices: Evidence from Indonesia. KnE Social Sciences, 3(13), 499. https://doi.org/10.18502/kss.v3i13.4226.

Mechri, N., Ben Hamad, S., de Peretti, C., and Charfi, S. (2019). The Impact of the Exchange Rate Volatilities on Stock Markets Dynamics: Evidence from Tunisia and Turkey. SSRN Electronic Journal. https://doi.org/10.2139/ssrn.3304040.

Megaravalli, A. V., and Sampagnaro, G. (2018). Macroeconomic Indicators and Their Impact on Stock Markets in ASIAN 3: A Pooled Mean Group Approach. Cogent Economics and Finance, 6(1), 1-14. https://doi.org/10.1080/23322039.2018.1432450.

Muktadir-Al-Mukit, D. (2013). The Effects of Interest Rates Volatility on Stock Returns: Evidence from Bangladesh. International Journal of Management and Business Research, 3(3), 269-279. 
Omotor, D. G. (2009). Relationship between Inflation and Stock Market Returns: Evidence from Nigeria. Journal of Applied Statistics, 1(1), 1-15.

Pal, R. (2018). Theory of Interest Rate Determkination. In Theory of Interest Rate.

Peiró, A. (2016). Stock Prices and Macroeconomic Factors: Some European Evidence. International Review of Economics and Finance, 41, 287-294. https://doi.org/10.1016/j.iref.2015.08.004.

Phan, D. H. B., Sharma, S. S., and Narayan, P. K. (2015). Stock Return Forecasting: Some new Evidence. International Review of Financial Analysis, 40, 38-51. https://doi.org/10.1016/j.irfa.2015.05.002.

PRC. (2015). The Future of World Religions: Population Growth Projections, 2010-2050. Retrieved January 9, 2020, from Pew Research Center website: https://www.pewforum.org/2015/04/02/religious-projections-2010-2050/

Rjoub, H., Türsoy, T., and Günsel, N. (2009). The Effects of Macroeconomic Factors on Stock Returns: Istanbul Stock Market. Studies in Economics and Finance, 26(1), 36-45. https://doi.org/10.1108/10867370910946315.

Sukruoglu, D., and Temel Nalin, H. (2014). The Macroeconomic Determinants of Stock Market Development in Selected European Countries: Dynamic Panel Data Analysis. International Journal of Economics and Finance, 6(3), 64-71. https://doi.org/10.5539/ijef.v6n3p64.

Tripathi, V., and Kumar, A. (2015). Relationship Between Inflation and Stock Returns Evidence from BRICS Markets Using Panel Co Integration Test. International Journal of Accounting and Financial Reporting, 1(1), 647. https://doi.org/10.5296/ijafr.v4i2.6671.

Wahyudi, I., and Sani, G. A. (2014). Interdependence Between Islamic Capital Market and Money Market: Evidence from Indonesia. Borsa Istanbul Review, 14(1), 32-47. https://doi.org/10.1016/j.bir.2013.11.001. 